Hydrology and Earth System Sciences, 8(2), 266-275 (2004) C $\quad$ EGU

\title{
Seasonal and diurnal hydro-chemical variations in a recreated reed bed
}

\author{
C.J. Stratford ${ }^{1}$, M.P. McCartney ${ }^{2}$ and R.J.Williams ${ }^{1}$ \\ ${ }^{1}$ Centre for Ecology and Hydrology, Maclean Building, Crowmarsh Gifford, Wallingford, Oxfordshire, OX10 8BB, United Kingdom \\ ${ }^{2}$ International Water Management Institute, Africa Office, Private Bag X813, 0127 Silverton, Pretoria, South Africa
}

Email for corresponding author: cstr@ceh.ac.uk

\begin{abstract}
The widespread loss and degradation of UK wetlands over the last 200 years has resulted in a loss of habitat for wading and migrating birds To help stem this decline, wetland areas are now being preserved and where possible created. This study investigated water quality in a recreated reed bed in south-west England designed specifically to provide habitat for birds. Since June 2000, continuous measurements of temperature, $\mathrm{pH}$, electrical conductivity and dissolved oxygen have been logged. These data enable the partial pressure of $\mathrm{CO}_{2}$ to be calculated. This paper looks at the data collected up to November 2001. Despite similar solar radiation and water temperature conditions in both 2000 and 2001, peak summertime values of dissolved oxygen dropped from $>100 \%$ to $<50 \%$ and $\mathrm{pH}$ values dropped from $>7.7$ to $<7.2$. Both also show a reduction in diurnal variation. Over the same period, the average partial pressure of $\mathrm{CO}_{2}$ increased from 19.7 to 56.1 . Analysis of the diurnal dissolved oxygen curves indicates a decrease in photosynthesis which, in the absence of a change in nutrient concentrations in the water, may result from surface plant growth or from a reduction in submerged plant cover. The implications of these changing hydro-chemical conditions are that the site will be less able to support such a wide diversity of aquatic fauna, which will reduce the effectiveness of the site as a habitat for some bird species.
\end{abstract}

Keywords: wetland, reed bed, hydrochemistry, dissolved oxygen, pH, continuous monitoring, Hamwall, Somerset Levels

\section{Introduction}

The area of wetland in the UK has decreased rapidly since the industrial revolution in the 18 th and 19 th centuries when land drainage became an important feature of agricultural, urban and industrial development (Acreman and Jose, 2000). Indeed, the most common wetland types in Europe are 'lost', 'degraded' and 'threatened' (Hollis and Jones, 1991). Areas that have been particularly affected include lowland raised bogs and fens, which have become degraded as a result of peat extraction for fuel and horticulture. It is estimated that of an original lowland raised bog area in the UK of 69664 ha, only 3836 ha remains in its 'near natural' state (ODPM, 1999).

Peatlands or mires are of high conservation value, supporting highly specialised plant communities (Heathwaite and Hughes, 1995). To protect the remaining peatland areas, no planning permissions to extract peat from new sites have been granted since 1994. Consequently current extraction is focused on those areas that have already been significantly damaged by extraction (ODPM, 1999). The conclusions of the 1994 UK government working group on peatlands were: " 1 . to protect areas of high conservation value from future development and 2. to ensure that all damaged peatlands were reclaimed to a beneficial use (generally wetland habitats) once peat extraction ceased". By 2014 it is estimated that 17 peatbogs will have ceased to be worked providing an estimated 4000 ha of regenerating peatland, the majority of which could be restored for conservation purposes (OPDM, 1999).

In addition to the decline of peatlands, it is estimated that in the UK there has been a $40 \%$ reduction in reed bed habitat since 1945 (Bibby et al., 1989). Reedbeds are crucial habitat for a number of bird species including the Marsh Harrier, Bittern and Bearded Tit (Merritt, 1994). Where conditions are suitable (e.g. there is a reliable water supply, easy control of water levels, no saline intrusion and either level or very shallow gradient (Hawke and José, 1996)) one option for the restoration of worked-out peatlands is the creation of 
reed beds (McCartney et al., 2002). Reed bed creation is a quick way to establish mature habitat, often taking less than five years to reach full cover (Hawke and José, 1996). In addition to providing habitat, reed beds also act as water treatment systems able to remove nutrients from agricultural runoff (Fisher and Acreman, 2004), and help to meet the increasing demand for cut reed from the UK thatching industry. Reed bed creation is not limited to worked peatlands. Other successfully restored sites include disused clay pits (e.g. Barton and Barrow Clay Pits Site of Special Scientific Interest, Humberside, UK) and disused opencast coal mines (e.g. East Chevington, Northumberland, UK).

Once created or restored, active management of reed bed environments is necessary to prevent them drying out, becoming colonised by grasses and tall herbs, and eventually developing into scrub and woodland (Hawke and José, 1996). Currently, the lack of management of UK reed beds is resulting in an overall deterioration of the quality of the habitat and reed itself. Key management practices are: (1) water level control, which is required to encourage reed growth at the expense of other plant species to increase the rate of litter break down (after draw-down) and to optimise aquatic habitat; and (2) reed cutting, which is required to reduce the rate of litter accumulation, stimulate the production of new buds, and control reed encroachment into open water (Hawke and José, 1996).

Both of these practices can influence water quality (e.g. by diluting nutrients present in the water or by creating a build up of organic matter). It is therefore important to monitor hydro-chemical conditions and to attempt to prevent conditions developing that are detrimental to the flora and fauna at the site.

Dissolved oxygen, $\mathrm{pH}$ and temperature are crucial to understanding how wetlands function (Seybold et al., 2002; Rose and Crumpton, 1996) and monitoring of them must be frequent and regular enough to detect the seasonal and diurnal processes that occur (Ross, 1995). Water quality monitoring usually occurs during the day although the lowest dissolved oxygen and highest $\mathrm{pH}$ values, associated with biological processes within the water body, normally occur at night (Neal et al., 2002). Consequently, a common constraint of hydro-chemical data is that they give an incomplete picture of what is going on in relation to the important issues of oxygen depletion and water quality change and hence the health of an aquatic ecosystem. Continuous monitoring enables quantification and analysis of the diurnal cycles of dissolved oxygen and $\mathrm{pH}$ that result from primary production and respiration (e.g. Odum, 1956; Edwards and Owens, 1965). It also facilitates the identification of extended periods of low dissolved oxygen, which may lead to fish kills and make the wetland an unsuitable habitat for some invertebrate and fish species.

Whilst several studies have examined these processes in natural wetland environments (e.g. Seybold et al., 2002 and Murkin et al., 1992) and shallow lakes (e.g. Ansa-Asare et al., 1999), few studies have been conducted on the increasing number of re-created wetland environments where rapid development of habitat and active management are key characteristics. In June 2000, monitoring was initiated at Hamwall, a constructed reed bed in an area of formerly worked-out peat, in response to reported fish kills. This work builds on earlier studies carried out by $\mathrm{CEH}$ Wallingford looking at the hydrology of reed bed creation (Gilman et al., 1998) and at water quality trends (McCartney et al., 2003). While McCartney et al. (2003) discuss fortnightly nutrient data, this paper presents data on the temporal variations in continuous dissolved oxygen and $\mathrm{pH}$ measurements.

\section{Materials and methods}

\section{STUDY SITE}

The study site, Hamwall, lies within the Somerset Levels and Moors (Fig. 1), a $600 \mathrm{~km}^{2}$ area of predominantly wet grassland in the south-west of England. The area is of international importance for over-wintering and migratory birds and for the invertebrates that live in the drainage ditches. $45 \%$ of the area is classed as an Environmentally

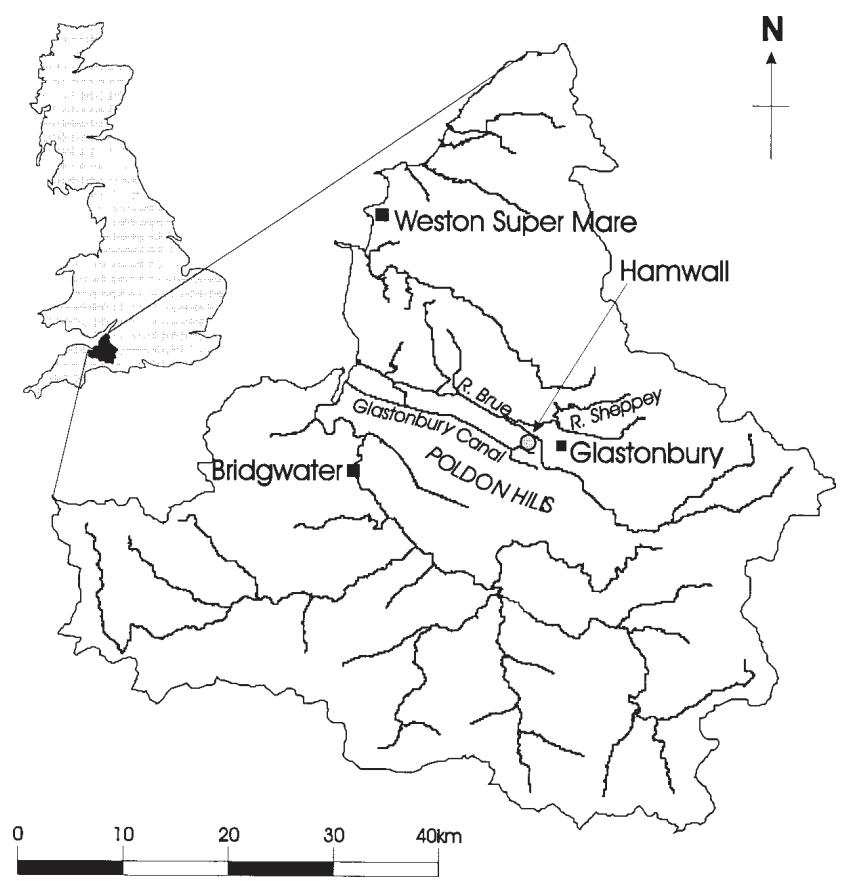

Fig. 1. Map showing the location of Hamwall in relation to the UK. 


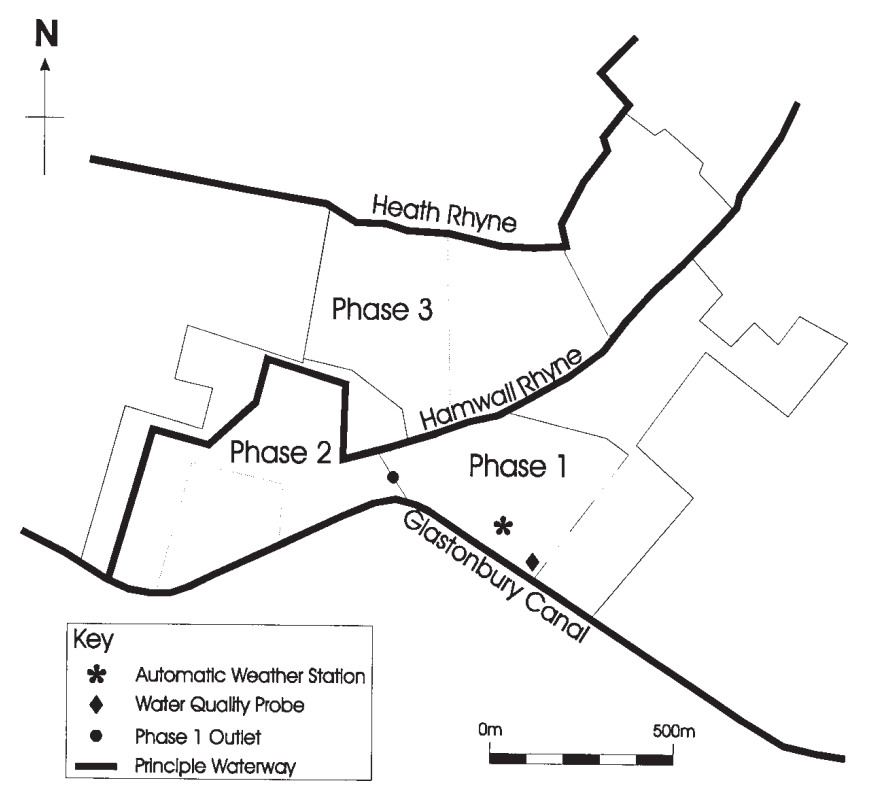

Fig. 2. Map showing the layout of the Hamwall RSPB reserve.

Sensitive Area (ESA), $12 \%$ as Sites of Special Scientific Interest, $10 \%$ as a Special Protection Area and it is also classified as a Ramsar site (Environment Agency, 2000; Davis, 1994).

The landscape has developed from the reclamation of tidal marshes and is now characterised by extensive low-lying areas of alluvium and peat, broken by low hills (McCartney et al., 2002). Extensive peat extraction during the 1960s and 1970s left large areas of disturbed peat and clay at levels lower than natural ground level. Although some peat extraction continues, the area is now dominated by dairy and arable farming.

Hamwall (Fig. 2) is a 140 ha area of old peat workings which is being converted by the Royal Society for the Protection of Birds (RSPB) with the aim of creating and maintaining suitable habitat to support rare wetland bird species such as the bittern and marsh harrier. The disturbed soils left by peat extraction are unsuitable for the immediate re-establishment of the 'natural' acid bog habitats that existed before excavation (Ingrouille, 1995), so instead the site has been planted with common reed (Phragmatis australis) and reedmace (Typha latifolia).

The site is underlain by 4 to $8 \mathrm{~m}$ of blue-grey estuarine clay. As a result there is negligible exchange with ground water. The reed bed has been constructed in phases, with separate compartments created at different times. Construction of the bunds started in the summer of 1994. The phase 1 reeds were planted in a 17 ha compartment in 1995 (Fig. 2). The phase 2 compartment, which consists of 23 ha of reed bed, was planted in summer 1996. Clay was used to line the individual compartments of the reserve giving a high level of isolation between compartments. A clay embankment separates the phase 1 and 2 compartments. Within the phase 1 compartment the water is generally either still or very slow moving.

This paper considers only phase 1 of the Hamwall site. The water in phase 1 was pumped in originally from the Hamwall Rhyne, which drains agricultural land to the north of the wetland, and the Glastonbury Canal. Further pumping from the Hamwall Rhyne into the north end of the site takes place as necessary to maintain desired water levels. Water from phase 1 is sometimes allowed to flow into phase 2 via a control sluice. However, when the sluice is closed, phase 1 and phase 2 are hydrologically isolated units and the primary inputs and outputs of water in phase 1 are rainfall and evaporation respectively. Gilman et al. (1998) estimated that there is some leakage from the northern boundary of phase 1 into the Hamwall Rhyne. At depths greater than $1.0 \mathrm{~m}$, leakage is estimated to be $550 \mathrm{~m}^{3} \mathrm{~d}^{-1}$, dropping to zero when water levels fall to less than $0.6 \mathrm{~m}$.

\section{AUTOMATIC WEATHER STATION (AWS) DATA}

Hourly meteorological data have been collected at Hamwall since 1995 using an automatic weather station operated and maintained by Somerset County Council. Rainfall (mm), water depth (m), wind speed $\left(\mathrm{m} \mathrm{s}^{-1}\right)$ and direction (degrees), incoming solar radiation ( $\mathrm{MJ} \mathrm{m}^{-2}$ ) with a spectral range of 305 to $2800 \mathrm{~nm}$, and photosynthetically active radiation (PAR) $\left(\mathrm{Mol} \mathrm{m}^{-2} \mathrm{~s}^{-1}\right)$ with a spectral range of 400 to $700 \mathrm{~nm}$ are logged on an hourly time step.

\section{WATER QUALITY MEASUREMENTS}

The sampling and monitoring began in June 2000 . Continuous measurements of temperature, conductivity, dissolved oxygen and $\mathrm{pH}$ were logged on a 15 minute time step using 'YSI' multi-parameter water quality monitors (YSI, Yellow Springs, Ohio USA). Two units were used, changing over every 15 to 19 days. The sensors were suspended at a depth of $20 \mathrm{~cm}, 2 \mathrm{~m}$ from the water edge (Fig. 2). Reeds were present along the bank, and to about $1.5 \mathrm{~m}$ from the water edge (i.e. $0.5 \mathrm{~m}$ from the instrument). Details of instrument calibration and data correction are given in appendix A.

\section{EXCESS $\mathrm{CO}_{2}$ PRESSURE CALCULATION}

The amount of $\mathrm{CO}_{2}$ dissolved in the water $\left(\mathrm{EpCO}_{2}\right)$ was used as an additional indicator of the photosynthesis and respiration occurring. EpCO $\mathrm{CO}_{2}$ is defined as:

$$
\mathrm{EpCO}_{2}=\left\{\mathrm{H}_{2} \mathrm{CO}_{3 \text { water }}^{0^{*}}\right\} /\left\{\mathrm{H}_{2} \mathrm{CO}_{3 \text { eqm }}^{0^{*}}\right\}
$$


$\left\{\mathrm{H}_{2} \mathrm{CO}_{3 \text { water }}^{0^{*}}\right\}$ is the activity of $\mathrm{CO}_{2}$ dissolved in the water being studied and $\left\{\mathrm{H}_{2} \mathrm{CO}_{3 \text { eqm }}^{0^{*}}\right\}$ is the activity of $\mathrm{CO}_{2}$ in the same water in equilibrium with the atmosphere. Thus a value of 1 indicates equilibrium with the atmosphere (Neal et al., 2002). $\mathrm{EpCO}_{2}$ was calculated from the temperature (T), $\mathrm{pH}$ and alkalinity of the water (Eqn. 2) following the approach of Neal et al. (2000).

$$
\begin{array}{r}
\mathrm{EpCO}_{2}=\left(0.95 *\left([\text { Alkalinity }]+10^{6-p H}\right) * 10^{6-p H}\right) \\
/(6.46-0.0636 T)
\end{array}
$$

Both $\mathrm{pH}$ and temperature were recorded by the water quality probes and alkalinity was calculated from specific conductivity. Alkalinity was linearly related to conductivity and a regression was used to calculate alkalinity from the conductivity data collected by the probe. The linear relationship was:

$$
\text { Alkalinity }=8.3 * \text { Conductivity }+330.6
$$

$\left(\mathrm{n}=59, \mathrm{r}^{2}=0.72\right.$, F-statistic: 145.1 on 1 and 54 degrees of freedom, $\mathrm{p}=1.1 \times 10^{-16}$ )

\section{Results}

\section{TIME SERIES DATA}

This paper discusses data collected between the 16th June 2000 and the 26th November 2001. During this time there were several periods during which no hydro-chemical data were collected: 4th March to 8th June 2001, when it was not possible to access the site due to an outbreak of Foot and Mouth disease, and six periods of 1 to 2 weeks due to battery failure and instrument malfunction. In addition, the water level sensor on the AWS malfunctioned between 31 st May 2001 and 2nd August 2001. The collection and maintenance of the continuous data are important and hard fought for and such missing gaps are to be expected ( $c f$ Neal et al., 2000).

The complete time series data are shown in Fig. 3 and summarised in Table 1. Incoming solar radiation and temperature (Fig. 3a), wind speed (Fig. 3c), dissolved oxygen (Fig. 3e) and pH (Fig. 3f) are sufficiently described by Table 1, however rainfall (Fig. 3b) and water depth and electrical conductivity (Fig. 3d) are described in greater detail below.

\section{Rainfall}

The long term (1964 to 2000) average annual rainfall for the River Brue catchment is $902 \mathrm{~mm}$ (Marsh and Lees,
2003). The annual rainfall during the monitoring period was $1467 \mathrm{~mm}$ in 2000 and $647 \mathrm{~mm}$ from the 1st January to the 30th November 2001: Fig. 3b shows daily rainfall for the study period. Heavy rainfall in the few days leading up to the 1st November 2000 caused the Glastonbury Canal to overtop its banks and flood into the reserve.

\section{Water depth and electrical conductivity}

Water depth varies between $0.59 \mathrm{~m}$ and $1.36 \mathrm{~m}$ and values are generally higher in winter as a result of increased rainfall and decreased evaporation (Fig. 3d). From summer 2000, water depth decreases reaching a minimum of $0.59 \mathrm{~m}$ in early September. It then increases steadily to $0.78 \mathrm{~m}$ until the 1st November 2000 at which point the Glastonbury Canal overtopped its banks and flooded into phase 1 . The result was a rapid increase in water depth to $1.2 \mathrm{~m}$. The level then continued to increase gradually from $1.2 \mathrm{~m}$ to $1.36 \mathrm{~m}$ until April 2001 at which time the level starts dropping again. During the period of missing data the water depth drops from $1.2 \mathrm{~m}$ to $0.8 \mathrm{~m}$. Despite the considerable difference in rainfall between 2000 and 2001, the summer and autumn water levels in both years are similar. During August and September a leak developed in a normally closed inflow pipe from the Glastonbury Canal and water flowed into phase 1 from the canal for a period of approximately one month. However, the inflow is undetectable from the depth data. No pumping into phase 1 was necessary during the monitoring period as water levels were maintained by the above average rainfall in 2000 and the flood from the Glastonbury Canal.

Electrical conductivity ranges between 418 and $562 \mu \mathrm{S}$ $\mathrm{cm}^{-1}$. Between June and November 2000, conductivity rises and falls between 450 and $550 \mu \mathrm{S} \mathrm{cm}^{-1}$ in a pattern that is the inverse of water level. It then drops to a minimum value of $418 \mu \mathrm{S} \mathrm{cm}^{-1}$ as a result of the flood from the Glastonbury Canal. Values remain low until water flows in from the Glastonbury Canal through the broken pipe. This causes a rapid rise in conductivity from 440 to $560 \mu \mathrm{S} \mathrm{cm}^{-1}$ over a period of 1 month, and this is followed by a gradual decrease to $470 \mu \mathrm{S} \mathrm{cm}^{-1}$.

\section{MINUTE DATA}

Two representative weeks, the 1 st to 8 th September, have been chosen from the late summers of 2000 and 2001 to illustrate the diurnal variations and to show changes from one year to the next. The reasons for choosing these weeks are: (1) the data were complete and clean and (2) the incoming PAR was similar in both periods making comparison more straightforward. The following section focuses on these periods. 


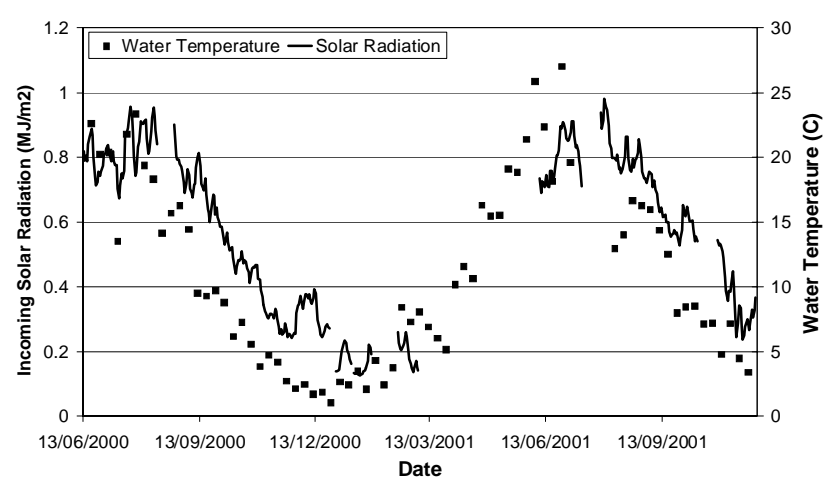

Fig. 3a. Incoming solar radiation and water temperature.

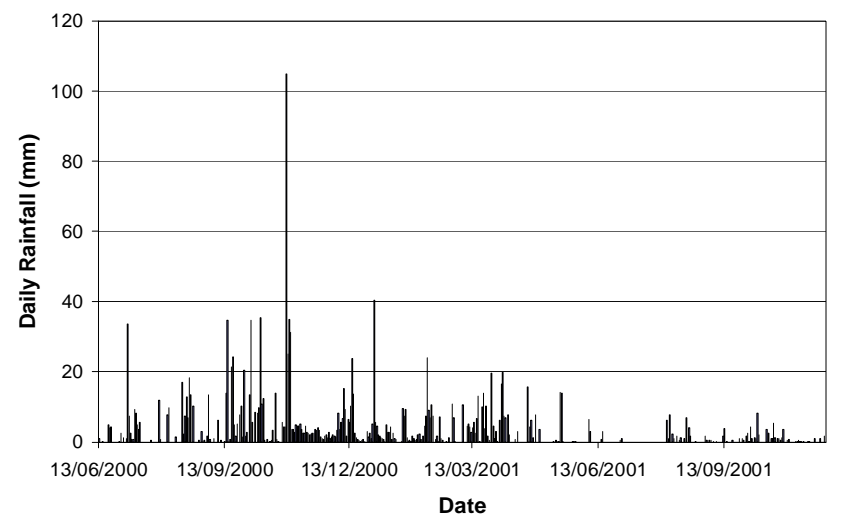

Fig. 3c. Daily total rainfall.

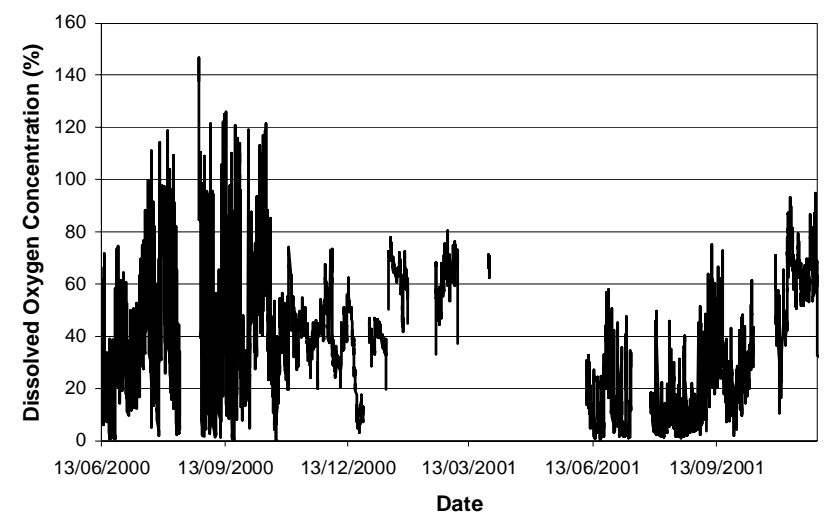

Fig. 3e. Hourly average dissolved oxygen values showing diurnal range.

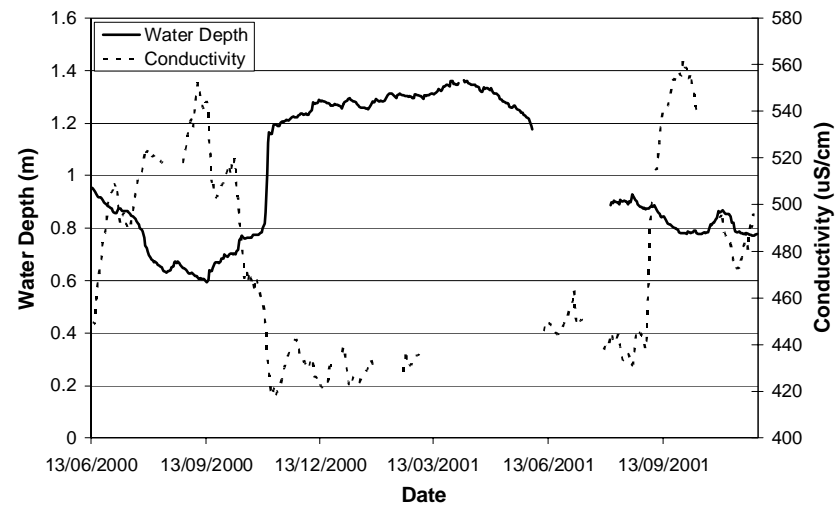

Fig. 3b. Water depth and electrical conductivity.

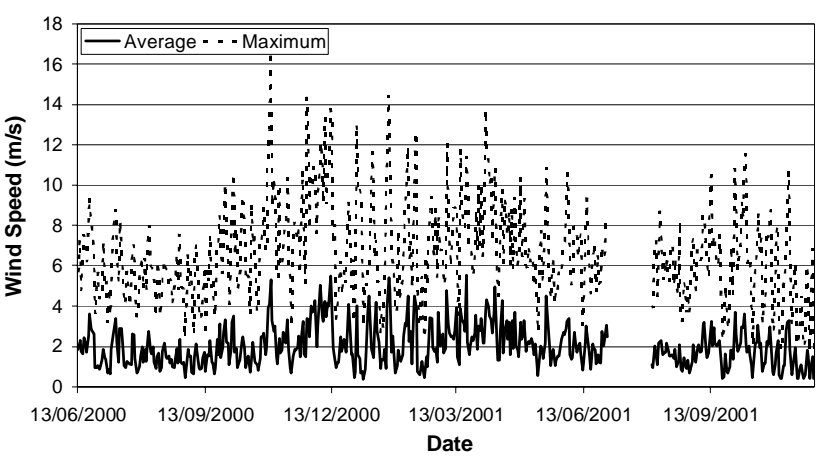

Fig. 3d. Daily average and daily maximum wind speed

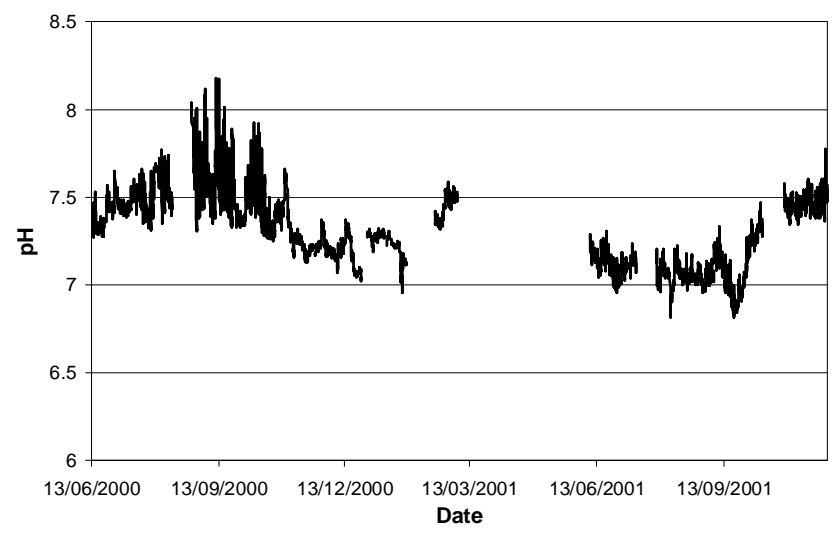

Fig. 3f. Hourly average $p H$ values showing diurnal range.

Fig 3. Graphs of full time series data for Hamwall, Somerset, UK. (Breaks in data lines indicate missing data.)

\section{PAR and dissolved oxygen}

In both years PAR varied between 0 and $4.5 \mathrm{~mol} \mathrm{~m}^{-2} \mathrm{~s}^{-1}$ and the overall levels of PAR are similar in both years (Fig. 4a and Fig. 4b). Dissolved oxygen follows closely the diurnal pattern of PAR, with peak values occurring between midday and $2 \mathrm{pm}$, and minimum values between $10 \mathrm{pm}$ and $3 \mathrm{am}$. Peak dissolved oxygen concentrations are reduced in 2001 compared to 2000 .
pH and EpCO

Figures 5a and 5b show pH and $\mathrm{EpCO}_{2}$ in 2000 and 2001 respectively. $\mathrm{pH}$ shows both an average drop of about $0.5 \mathrm{pH}$ units and a reduction in the diurnal variation from one year to the next. The diurnal variation in 2000 is up to 0.7 whereas in 2001 it has reduced to a maximum of 0.4. In 2000, $\mathrm{EpCO}_{2}$ is between 10 and 30 times atmospheric pressure but in 2001 it varies between 50 and 70 times atmospheric pressure. 
Table 1. Summary of time series data collected at Hamwall RSPB reserve. Mean, maximum, minimum and mean diurnal range are shown for summer (April to September) and winter (October to March) of 2000 and 2001. Mean diurnal range has been omitted for those parameters that do not exhibit a regular diurnal cycle.

\begin{tabular}{|c|c|c|c|c|c|c|c|c|}
\hline & $\begin{array}{l}\text { SuMmer } \\
\text { Mean }\end{array}$ & $\operatorname{Max}$ & Min & $\begin{array}{l}\text { Mean diurnal } \\
\text { range }\end{array}$ & $\begin{array}{c}\text { WINTER } \\
\text { Mean }\end{array}$ & $\operatorname{Max}$ & Min & $\begin{array}{l}\text { Mean diurnal } \\
\text { range }\end{array}$ \\
\hline \multicolumn{9}{|l|}{2000} \\
\hline Incoming Solar Radiation $\left(\mathrm{MJ} / \mathrm{m}^{2}\right)$ & 0.65 & 1.31 & 0.13 & 2.27 & 0.18 & 0.59 & 0.01 & 0.93 \\
\hline Temperature $(\mathrm{C})$ & 19.49 & 23.92 & 14.68 & 2.80 & 7.56 & 14.23 & 3.12 & 0.75 \\
\hline Wind Speed $(\mathrm{m} / \mathrm{s})$ & 1.61 & 3.61 & 0.44 & & 2.35 & 5.53 & 0.34 & \\
\hline Water Depth (m) & 0.74 & 0.95 & 0.59 & & 1.19 & 1.36 & 0.70 & \\
\hline Electrical Conductivity $(\mu \mathrm{S} / \mathrm{cm})$ & 510.30 & 552.42 & 448.69 & & 442.36 & 519.61 & 418.03 & \\
\hline DO $(\%)$ & 45.13 & 146.65 & 0.00 & 55.32 & 47.42 & 121.55 & 0.18 & 17.70 \\
\hline $\mathrm{pH}$ & 7.51 & 8.18 & 7.27 & 0.22 & 7.31 & 7.93 & 6.96 & 0.11 \\
\hline \multicolumn{9}{|l|}{2001} \\
\hline Incoming Solar Radiation $\left(\mathrm{MJ} / \mathrm{m}^{2}\right)$ & 0.65 & 1.26 & 0.08 & 2.47 & 0.23 & 0.49 & 0.04 & 1.70 \\
\hline Temperature $(\mathrm{C})$ & 18.93 & 24.52 & 13.20 & 2.24 & 10.55 & 16.19 & 5.92 & 1.30 \\
\hline Wind Speed $(\mathrm{m} / \mathrm{s})$ & 2.01 & 4.96 & 0.43 & & 1.57 & 3.61 & 0.38 & \\
\hline Water Depth $(\mathrm{m})$ & 1.08 & 1.36 & 0.78 & & 0.80 & 0.87 & 0.77 & \\
\hline Electrical Conductivity $(\mu \mathrm{S} / \mathrm{cm})$ & 472.36 & 561.84 & 430.93 & & 499.77 & 558.41 & 472.29 & \\
\hline DO $(\%)$ & 18.96 & 75.33 & 0.00 & 25.50 & 54.25 & 95.05 & 10.18 & 20.86 \\
\hline $\mathrm{pH}$ & 7.07 & 7.34 & 6.82 & 0.12 & 7.43 & 7.77 & 7.17 & 0.13 \\
\hline
\end{tabular}
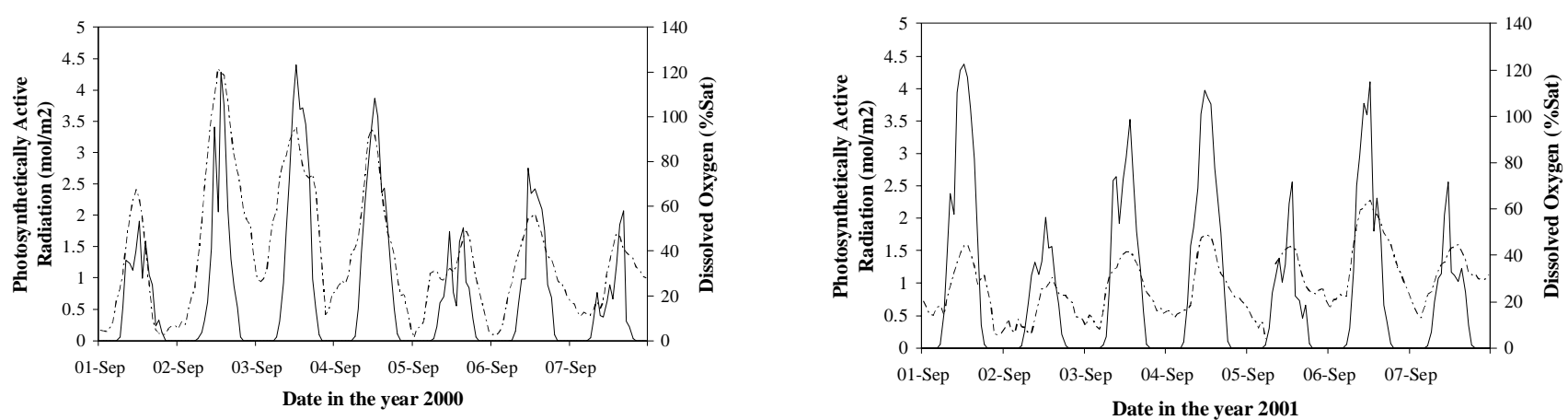

Fig. 4. PAR and dissolved oxygen for the period $1^{\text {st }}$ September to $8^{\text {th }}$ September in the years 2000 (left) and 2001 (right).

\section{Discussion}

The factors affecting hydro-chemical conditions in aquatic ecosystems are numerous, complex and interlinked. For instance, both dissolved oxygen and dissolved carbon dioxide are controlled by: (1) photosynthesis during the day by plants, releasing oxygen and taking up carbon dioxide, (2) respiration by plants at night and microbial breakdown of organic matter during the day and night, releasing carbon dioxide and taking up oxygen and (3) the physical transfer of oxygen and carbon dioxide between the water body and the atmosphere (Neal et al., 2000). In turn, these processes are affected by incoming solar radiation (photosynthesis), water temperature (respiration) and flow velocity, turbulence and wind speed (physical gaseous exchange) (Ginot and Herve, 1994). Additional effects such as an increase in dissolved oxygen concentration with decreasing water depth have also been observed in other studies (Sabo et al., 1999).

Solar radiation and water temperature show a high degree of similarity in the two years (Fig. 3a). Elevated temperatures in summer increase the rate of respiration in comparison to lower winter temperatures and result in a greater oxygen sag at night whilst submerged plants are not photosynthesising. This is illustrated in Fig. 3e by the greater number of low values in the summer months compared to 

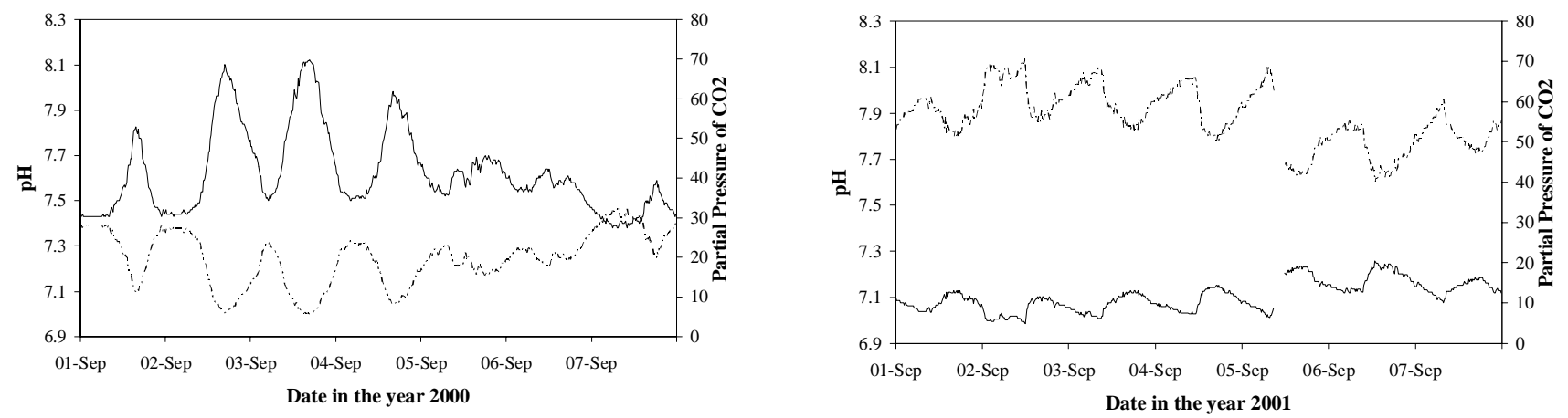

Fig. 5. $\mathrm{pH}$ and the calculated partial pressure of $\mathrm{CO}_{2}$ for the period $1^{\text {st }}$ September to $8^{\text {th }}$ September in the years 2000 (left)and 2001 (right).

winter. Kominkova et al. (2000) studied the decomposition of Phragmites Australis in a reed stand of a large lake and found a close correspondence between lake water temperature and respiration. They concluded that observed changes in respiration were primarily governed by temperature. This is part of the reason why the greatest oxygen stresses tend to occur during warm weather. The negligible difference in solar radiation and water temperature between years indicates that neither plays a significant role in causing the observed inter-annual variation in dissolved oxygen or $\mathrm{pH}$.

Conductivity is controlled largely by inputs of water from different sources. Rainfall, with a typical conductivity of $25 \mu \mathrm{S} \mathrm{cm}^{-1}$, and surface runoff carried by the Glastonbury Canal during high flows such as when it over topped its banks, both have a diluting effect and cause a drop in conductivity. By contrast, carbonate-rich groundwater inputs such as the water carried by the Glastonbury Canal in low flow conditions have a higher conductivity (average winter value of $903 \mu \mathrm{S} \mathrm{cm}^{-1}$ and summer value of $782 \mu \mathrm{S} \mathrm{cm}^{-1}$ (McCartney et al., 2003)) and when they entered phase 1 through a broken pipe (August and September 2001) they caused an increase in conductivity. Although these are the dominant controls, heterotrophic organisms may influence conductivity through the release or uptake of dissolved substances (Madigan et al., 1997). The maintenance of the relatively high conductivities observed suggests some reaction between the carbonate minerals in the sediment and the water column (McCartney et al., 2003).

The large diurnal variations in dissolved oxygen of up to $150 \%$ in the summer of 2000 suggest conditions of high productivity with high rates of photosynthesis during the day. The diurnal patterns observed here are typical of productive environments and have been noted at a variety of other sites, including shallow ponds, with a diurnal range of $130 \%$ (Ginot and Herve, 1994) and densely vegetated rivers with a diurnal range of $150 \%$ (Williams et al., 2000).
As the concentration of dissolved $\mathrm{CO}_{2}$ is controlled by the same processes as those controlling dissolved oxygen, there is also a strong diurnal variation in $\mathrm{pH}$. The diurnal variations are reduced in winter, indicating reduced productivity as a result of shorter and less intense periods of daylight. The $\mathrm{CO}_{2}$ concentrations are constantly above 1 indicating supersaturation, and are at times 70 times atmospheric pressure. Neal et al., (2000) observed similar concentrations in the River Kennet although the diurnal variations were at times much greater than recorded at Hamwall. A reason for this difference could be the greater amount of submerged macrophyte cover in the River Kennet compared to Hamwall which takes up $\mathrm{CO}_{2}$ during the day and releases it at night. The overall high dissolved $\mathrm{CO}_{2}$ concentrations at Hamwall indicate the dominance of respiration over photosynthesis.

To better understand the processes bringing about these variations, the diurnal dissolved oxygen cycle was analysed using the single station Delta method, as developed by Chapra and Di Toro (1993). A detailed description of the method is given by Williams et al. (2000). Figures 6a, 6b and $6 \mathrm{c}$ show results of the analysis carried out on data collected between 9th June and 17th September in years 2000 and 2001 and the data are displayed as normal probability plots. The data are also summarised in Table 2 .

The calculated mean values of reaeration, photosynthesis and respiration were all greater in 2000 than in 2001. There

Table 2. Summary of results from Delta method analysis of dissolved oxygen data.

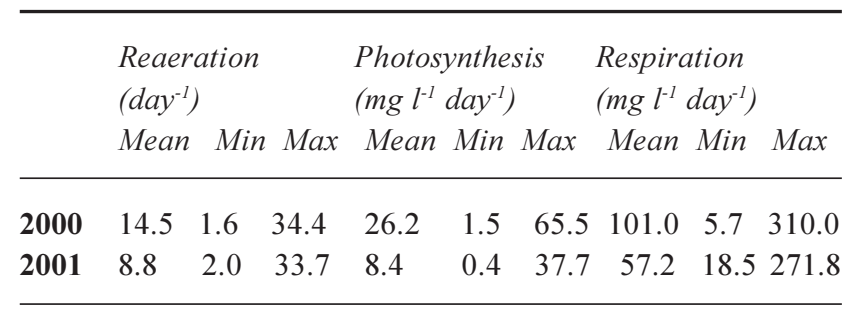


was also a reduction in the ranges of values from 2000 to 2001. However, the calculated values must be treated with some care because even though steps have been taken to minimise errors (e.g. by discounting results when the minimum dissolved oxygen deficit occurs before noon) the Delta method is very sensitive to time of lowest dissolved oxygen concentration (Williams et al., 2000). Given the sometimes complex nature of the dissolved oxygen curves recorded here, estimation of the dissolved oxygen deficit minima is difficult. Errors in this value greatly affect the calculation of reaeration, and the errors then propagate through the calculations of photosynthesis and respiration. If reaeration was much greater in 2001 then it may be expected that wind speeds would be greater. The wind speed data for the same period (Fig. 3d) shows both comparable average and maximum values between 2000 and 2001 and a large difference in reaeration would not therefore be expected.

The results of the Delta method analysis are broadly in line with the observed variations in $\mathrm{pH}$ and dissolved oxygen. The reduction in the diurnal variation of dissolved oxygen and $\mathrm{pH}$ in summer 2001 indicates a reduction in photosynthesis. This could result from surface growth preventing light penetrating to submerged vegetation or a decrease in the coverage of submerged macrophytes. A reduction in submerged macrophytes would also reduce the amount of respiration occurring at night. Nutrient data for the site presented by McCartney et al. (2003) do not show a clear downward trend in either nitrate or phosphate that could account for this decrease in productivity.

The ecological effects of low dissolved oxygen concentrations and $\mathrm{pH}$ are far reaching: Nelson et al. (2000) found that in a study of constructed wetlands in New Mexico, invertebrate taxa richness was positively related to dissolved oxygen concentration. The importance of invertebrates in wetland functioning and as a food source has promoted suggestions that invertebrates should be used, along with other criteria, to compare the state of wetlands (Streever et al., 1996). Fish are also at risk. In addition to the direct effects of oxygen depletion, which can cause changes in behaviour or death (Suthers and Gee, 1986), there could be a reduction in available food (invertebrates). Kramer (1987) noted that in response to low dissolved oxygen conditions, fish use the upper water column to increase surface breathing and this increases their risk of avian predation.

Low $\mathrm{pH}$ alone does not generally become harmful to fish until it drops below 6.4 (Wellburn, 1988). West et al. (1997) found that of nine species of freshwater fish, six avoided areas of water with a $\mathrm{pH}$ less than 6.5. This suggests that a gradual shift in $\mathrm{pH}$ may cause change species distribution.

The changes observed at this site must also be considered
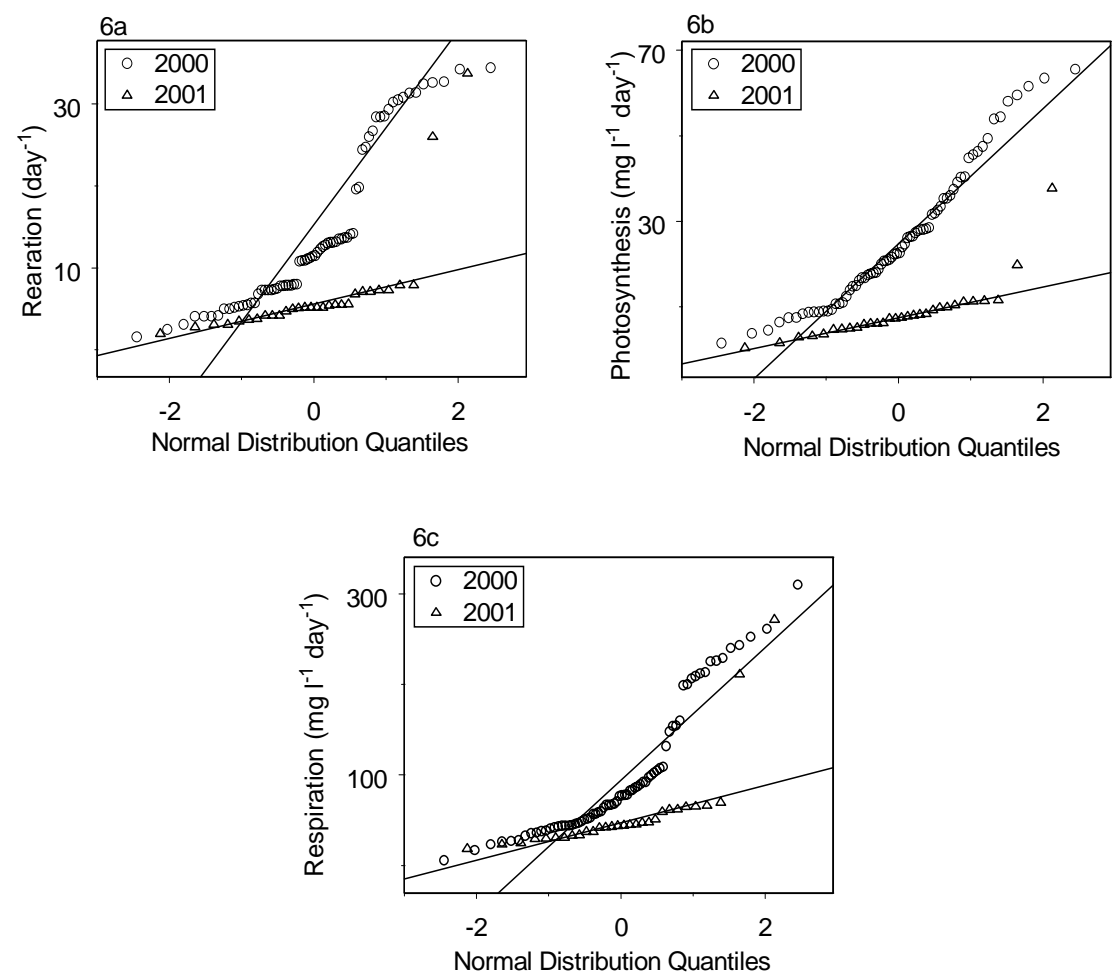

Fig. 6. Plots of calculated values of rearation (6a), photosynthesis (6b) and respiration (6c), using the Delta method. The comparison of results for 2000 and 2001 is shown. Lines of best fit are included to aid comparison. 
in relation to UK climate change over the past 20 years; summer rainfall has decreased by $10 \%$ and temperatures have increased by $0.6^{\circ} \mathrm{C}$ compared to the preceding average (Marsh and Sanderson, 1997). The associated increase in losses due to evapotranspiration has resulted in an increase in the frequency of drought conditions. Although water availability has not been discussed in this paper, water shortages in summer may move management towards keeping water levels high through the summer. This may increase the levels that dissolved $\mathrm{CO}_{2}$ can reach and therefore lowering $\mathrm{pH}$. The trend of increasing temperatures could lead to increased respiration rates, causing a further drop in $\mathrm{pH}$.

\section{Conclusions}

The results presented in this paper show that the hydrochemistry of this wetland changed dramatically over a period of 18 months. Both dissolved oxygen and $\mathrm{pH}$ decreased whilst dissolved $\mathrm{CO}_{2}$ concentrations increased. These changes have the potential to influence the type and range of aquatic flora and fauna in the reserve and this in turn may affect the suitability of the reserve for some bird species.

The site studied here is one of an increasing number of worked peatlands that are suitable for reed bed creation. Many of these have the potential to provide important habitat with a high conservation value. This research is in its early stages and this paper is intended to provide a background to this unique site typology and the processes within it. Continued and additional monitoring (to include macrophytes and algal diversity and abundance, improved nutrient analysis, turbidity measurements, and invertebrate and fish surveys) are required to better understand the system and to examine seasonal and inter-annual variation in the context of climate change and climate variability.

\section{Acknowledgements}

The authors are grateful to Sally Mills and Mike Johnson at the RSPB in Hamwall for their help with data collection and background information, and to Colin Neal for his advice and comments. They also thank Maëla Jaouen for her help with data processing.

\section{References}

Acreman, M.C. and José, P., 2000. Wetlands. In: The Hydrology of the UK - a study of change, M.C.Acreman (Ed.). Routledge, London. 204-224.
Acreman, M.C., Mountford, J.O., McCartney, M.P., Wadsworth, R.A., Swetnam, R.D., McNeil, D.D., Manchester, S.J., Myhill, D.G., Broughton, R.K. and Hudson, J., 2000. Integrating wetland management, catchment hydrology and ecosystem functions, First Annual Report, Centre for Ecology and Hydrology, Wallingford, UK, 48pp.

Ansa-Asare, O.D., Marr, I.L. and Cresser, M.S., 1999, Evaluation of cycling patterns of dissolved oxygen in a tropical lake as an indicator of biodegradable organic pollution. Sci. Total Envir., 231, 145-158.

Bibby, C., Housden, S., Porter, R. and Thomas, G., 1989. A conservation strategy for birds. RSPB unpublished report.

Chapra, S. C. and Di Toro, D. M., 1991. Delta measurement for estimating primary production, respiration and reaeration in streams. J. Environ. Eng., 117, 640-655.

Davis, T.J. (Ed.), 1994. The Ramsar Convention Manual: a guide to the convention on wetlands of international importance especially as waterfowl habitat. Ramsar Convention Bureau, Gland, Switzerland.

Edwards, R.W. and Owens, M., 1965. The oxygen balance of streams, ecology and the industrial society. Blackwell, Oxford, UK.

Environment Agency, 2000. Somerset Levels and Moors Water Level Management ActionPlan, Environment Agency, South West Region, Exeter, UK, 25pp.

Fisher, J. and Acreman, M.C., 2004. Wetland nutrient removal: a review of the evidence. Hydrol. Earth Syst. Sci. (in press).

Gilman, K., Hudson, J.A. and Crane, S.B., 1998. Final report on hydrological evaluation of reed bed re-creation at Ham Wall, Somerset. Institute of Hydrology, Wallingford, UK. 95pp.

Ginot, V. and Hervé, J-C., 1994. Estimating parameters of dissolved oxygen dynamics in shallow ponds. Ecol. Model., 73, 169-187.

Hawke, C.J. and José, P.V., 1996. Reed bed management for commercial and wildlife interests, The Royal Society for the Protection of Birds, Sandy, UK, 212pp.

Hollis, G.E. and Jones, T.A., 1991. Europe and the Mediterranean Basin. In: Wetlands. M. Finlayson and M. Moser (Eds.), International Wildfowl and Wetlands Research Bureau. Facts on File, Oxford, UK, 27-56.

Hughes, J.M.R. and Heathwaite, A.L., 1995. Introduction. In: Hydrology and Hydrochemistry of British Wetlands. J.M.R. Hughes and A.L. Heathwaite (Eds.), Wiley, Chichester, UK, 18.

Ingrouille, M., 1995. Historical Ecology of the British Flora. Chapman and Hall, London, UK, 347pp.

Komínková, D., Kuehn, K.A., Büsing, N., Steiner, D. and Gessner, M.O., 2000. Microbial biomass, growth and respiration associated with submerged litter of Phragmites australis decomposing in a littoral reed stand of a large lake. Aquat. microb. Ecol. 22, 271-282.

Kramer, D.L., 1987, Dissolved oxygen and fish behaviour. Envir. Biol. Fishes., 18, 81-92.

Madigan, M.T., Martinko, J.M. and Parker, J., 1997. Biology of Microorganisms. Prentice Hall, New Jersey 07458, USA.

Marsh, T.J. and Lees, M.L. (Eds.), 2003. Hydrological Data UK: Hydrometric Register and Statistics 1996 - 2000. Centre for Ecology and Hydrology, Wallingford, Oxfordshire, OX10 8BB.

Marsh, T.J. and Sanderson, F.J., 1997. A review of hydrological conditions throughout the period of the LOIS monitoring programme - considered within the context of recent UK climatic volatility. Sci. Total Envir. 194/195. 59-69.

McCartney, M.P., Stratford, C.J., Neal, C., Bradford, R., Mills, S. and Johnson, M. 2003. Seasonality and water quality trends in a maturing recreated reed bed. Sci. Total. Envir., 314-316, 233254. 
Merritt, A. 1994. Wetlands, Industry and Wildlife: A manual of principles and practices. Wildfowl and Wetlands Trust, Gloucester, UK, 182pp.

Murkin, E.J., Murkin, H.R. and Titman, R.D., 1992. Nektonic invertebrate abundance and distribution at the emergent vegetation-open water interface in the delta-marsh, Manitoba, Canada. Wetlands, 12, 45-52.

Neal, C., Watts, C., Williams, R.J., Neal, M., Hill, L., and Wickham, H., 2002. Diurnal and longer term patterns in carbon dioxide and calcite saturation for the River Kennet, south-eastern England. Sci. Total Envir., 282/283, 205-231.

Neal, C., Jarvie, H.P., Howarth, S.M., Whitehead, P.G., Williams, R.J., Neal, M., Harrow, M. and Wickham, H., 2000. The water quality of the river Kennet: initial observations on a lowland chalk stream impacted by sewage inputs and phosphorus remediation. Sci. Total Envir., 251/252, 477-495.

Neal, C., House, W.A., Jarvie, H.P. and Eatherall, A., 1998a. The significance of dissolved carbon dioxide in major lowland rivers entering the North Sea. Sci. Total Envir., 210/211, 187-204.

Neal, C., House, W.A. and Down, K., 1998b. Assessment of excess carbon dioxide partial pressures in natural waters based on $\mathrm{pH}$ and alkalinity measurements. Sci. Total Envir., 210/211, 173186.

Nelson, S.M., Roline, R.A., Thullen, J.S., Sartoris, J.J. and Boutwell, J.E., 2000. Invertebrate assemblages and trace element bioaccumulation associated with constructed wetlands. Wetlands. 20, 406-415.

ODPM, 1999. Peatland Issues - Report of the working group on peat extraction and related matters. Office of the Deputy Prime Minister. London, UK. 46pp.

Odum, H.T., 1956. Primary production in flowing rivers. Limnol. Oceanogr., 1, 102-117.

Rose, C. and Crumpton, W.G., 1996. Effects of emergent macrophytes on dissolved oxygen dynamics in a prairie pothole wetland. Wetlands. 16, 495-502.

Ross, S.M., 1995. Overview of the Hydrochemistry and solute processes in British wetlands. In: Hydrology and Hydrochemistry of British Wetlands. J.M.R. Hughes and A.L. Heathwaite (Eds.), Wiley, Chichester, UK, 135-181.

Sabo, M.J., Bryan, C.F., Kelso, W.E. and Allen Rutherford, D., 1999. Hydrology and aquatic habitat characteristics of a riverine swamp: 1. Influence of flow on water temperature and chemistry. Regul. Rivers, 15, 505-523.

Seybold, C.A., Mersie, W., Huang, J. and McNamee, C., 2002. Soil Redox, $\mathrm{pH}$, temperature, and water table patterns of a freshwater tidal wetland. Wetlands. 22, 149-158.

Streever, W.J., Portier, K.M. and Crisman, T.L., 1996. A comparison of dipterans from ten created and ten natural wetlands, Wetlands, 16, 416-428.

Suthers, I.M. and Gee, J.H., 1986. The role of hypoxia in limiting diel spring and summer distribution of juvenile yellow perch (Perca flavescens) in a prairie marsh. Can. J. Fisheries Aquat. Sci., 43, 1562-1570.

Wellburn, A., 1994, Air pollution and climate change: the biological impact. Longman, London, UK. 284pp.

West, D.W., Boubée, J.A.T. and Barrier, R.F.G., 1997. Responses to $\mathrm{pH}$ of nine fishes and one shrimp native to New Zealand freshwaters, N.Z. J. Mar. Freshwat. Res., 31, 461-468.

Williams, R.J., White, C., Harrow, M.L. and Neal, C., 2000. Temporal and small-scale spatial variations of dissolved oxygen in the Rivers Thames, Pang and Kennet, UK. Sci. Total Envir., 251/252, 497-510.

\section{Appendix A}

\section{CALIBRATION AND DATA CORRECTION PROCEDURES.}

The units were calibrated on the day before deployment in the field. A 2 point calibration was used for the $\mathrm{pH}$ electrodes, using $\mathrm{pH} 7.00$ and $\mathrm{pH} 9.18$ proprietary standard buffer solutions. The conductivity electrodes were calibrated using standard potassium chloride solution at $1413 \mu \mathrm{S} \mathrm{cm}^{-1}$ and cross-checked against a solution at $720 \mu \mathrm{S} \mathrm{cm}^{-1}$. Prior to dissolved oxygen calibration the unit was kept in a water bath, which was continuously bubbled with air and kept at room temperature, for 1 day to ensure that the membrane was properly wetted and in equilibrium. The membrane was then exposed to air in order to represent $100 \%$ saturation and the calibration was carried out. After this, a dissolved oxygen reading was taken in the continuously bubbled water bath, and this value was later used in correcting for instrument drift.

On return from the field, the units were tested using the same calibration procedure to check for drift in the instrument response. The units were then cleaned and stored in tap water before again being calibrated and deployed. When the units were swapped, grab samples were collected from next to the instrument. Prior to analysis, the waters were kept in filled and sealed glass bottles in order to minimise carbon dioxide degassing. These samples were analysed in the laboratory, usually the day after collection, for $\mathrm{pH}$, electrical conductivity and alkalinity.

The water quality probes were liable to drift whilst in the field as a result of dirt build up and fouling over time, and there was also a settle-in period during which the sensors would adjust to a new steady value. These effects could be compensated for by measuring the instrument response before and after deployment and calculating the change in response over time. In addition, $\mathrm{pH}$ and conductivity could be checked against the hand samples collected when changing probes. The correction factors were then applied to the data using the WISKI Hydrometric Information System (Kisters, Munich, Germany). This involved shifting the start and end points of the data set according to the pre and post deployment calibrations and applying a linear drift correction between them. Obvious spikes in the data set, especially those during the settling-period were removed. 